\title{
MANAGING ECO-FRIENDLY STRATEGY IMPLEMENTATION AND ITS IMPACTS ON BUSINESS PERFORMANCE: THE ROLE OF ORGANIZATIONAL STRATEGIC CAPABILITIES
}

\author{
Elok S. Pusparini* \\ Universitas Indonesia
}

Budi Widjaja Soetjipto

Universitas Indonesia

\author{
Riani Rachmawati \\ Universitas Indonesia
}

Lily Sudhartio

Universitas Indonesia

Uliyatun Nikmah

Universitas Indonesia

\begin{abstract}
The increasing movements on the implementation of environmental sustainability and its impact on business performance become one of the important discussions on the strategic management field. Organizations are forced to major environmental initiatives to answer the green business inquiries. Constructed from the organizational capabilities literature of strategic management, this study explains how organizations strengthen their performances toward the implementation of environmentaly friendly or also called as ecofriendly business strategy and proposes hypotheses to answer the questions on how the organizational capabilities that represents internal organizational factors affect business performance through the mediating effect of eco-friendly strategy implementation Using a model integrating resource-based theory, institutional theory, and strategic business unit perspectives, this study tests the causalities upon the hotel industry in Indonesia which currently facing the force to adopt environmental friendly business practices due to the expansive development within the industry. This study used SPSS software followed by mediation test to analyze the mediating effect of eco-friendly strategy implementation on the relationship between organizational strategic capabilities and business performance. Research data were collected through the questionnaires, resulting 109 data from two-starred and above hotels across major cities in Indonesia. The findings of this study indicate that organizational strategic capabilities have a positive and significant effect
\end{abstract}

\footnotetext{
* Corresponding author: Department of Management, Faculty of Economics and Business, Universitas Indonesia, Prof. Dr. Sumitro Djojohadikusumo Street, Kukusan, Beji, Depok City, West Java, Indonesia, 16424, Tel: +62217272425; Email:eloksp@ui.ac.id.
} 
on eco-friendly strategy implementation and business performances respectively while the mediating effect of Eco-friendly strategy implementation were partially found.Drawing from these results, the implications of the findings upon industrial, policies, and further research avenues are discussed.

Keywords: Business performance; eco-friendly business strategy; organizational strategic capabilities; hotel industry; Indonesia.

Received: 29 January 2019

Accepted: 11 June 2020

\section{INTRODUCTION}

Over the last decade, sustainability initiatives have become strategic focus for managerial decision makers in order to fulfill the demands from their employees, customers, governments, and other stakeholders (Aragon-Correa, Hurtado-Torres, Sharma, \& García-Morales, 2008; Chabowski, Mena, \& Gonzales-Padron, 2011). According to World Commision on Envrionment and Development (WECD) (1987), sustainability can be explained as stages of development to meet the needs in the present, without undermines the future generations' opportunities to meet their needs. Green business literature use eco-friendly, environmentaly friendly, and environmental sustainability interchangibly. Environmentaly friendly businesses are differentiated by their compliances beyond government regulations in order to align with growing environmental inquiries from their stakeholders (Buysse \& Verbeke, 2003). More research have been developed to identified firm level approaches to accomodate sustainability pressures and resulting four typologies, which are reactive, defensive, and accomodative, where each strategies reflect the role of social issues in shaping the strategic landscape of firm's strategy processes from the strategy formulation stages until strategy implementation stages (Clarkson, 1995; Hart, 1995).

Furthermore, Hart's (1995) seminal work explains the importance of elaborating environmental approach into strategic management literatures and proposed the natural resource-based view of the firm, resulting four approaches: the end-of-pipe approach, pollution prevention of total quality management (TQM) approach, product stewardship approach, and sustainable development approach. Authors including Christmann (2000), Rugman and Verbeke (2003), Sharma and Vredenburg (1998), and Buysse and Verbeke (2003) open more discussion on the implementation of environmental sustainability strategy as the reflection of the firm's level proactiveness. It is however, according to Arragon-Correa and Rubio-Lopez (2007), are determined upon the existance of organizational resources and capabilities (Peteraf, Stefano, \& Verona, 2013). Above all, organizational capabilities or in the words of the authors defined as organizational strategic capabilities, devided into 5 distinct categories; (1) marketing capabilities, (2) market-linking capabilities, (3) technological capabilities, (4) information technology capabilities, (5) management capabilities (Desarbo, Benedditto, Song, \& Sinha, 2005). These capabilities have been used to determine the increasing likelihood of an organization to introduce a new process after the acquisition of external research and development (Tsinopoulos, Sousa \& Yan 2018), also recently has been used to assess uncertainties and capabilities for market strategies and non-market strategies (Parnell, 2018) resulting a strong and significant relationship of the measured constructs. As Leonidou, Leonidou, Fotiadis \& Aykol (2015) suggest, discussion remain limited in the area such as the effect of company size, organizational design, top 
management education level, and green sensitive ladership, yet, study focuses on the strategic role of dynamic elements of the organization in order to imlement eco-friendly strategy remain unsaturated.

In attempt to answer the main research question on how the eco-friendly strategy implementation may leads to positive business performance, current study elaborate the five organizational capabilities as the predictors of the strategic decisions on eco-friendly strategy implementation. Main contribution of this study relies on the causal effect of each strategic capabilities on ecofriendly strategy implementation and the mediating roles of the eco-friendly strategy implementation in bridging the effect of the five strategic capabilities upon business performance. Six hypotheses were developed to test the model on the context of hospitality industry in Indonesia where growth in economy, rising global consumer purchasing power, and digital innovation have all motivated the growth in travel and hospitality industries, yet, several challenges could throw some major industries off in years ahead. Hotel industry as one of backbone in hospitality industries plays significant roles in contributing to environmental issues, including: (1) Water usage; many resorts and hotels have a lot of water waste from long guest showers and huge pools. In restaurants, they use water for dishes and often the machines are not efficient at saving water, (2) energy usage; this impacts all organizations in the hospitality industry. This includes the electricity of restaurants, hotels, and resorts, as well as the gas used by tourism, (3) food waste; frequently, foods are not reusable and are then thrown away. This creates problems for the environment, both in the action of throwing out the food and the demand it places on the environment to produce more, (4) pollution; whether these are used for energy or they are used for transportation, the amount of pollution caused by organizations in hospitality can be a big problem, (5) garbage/waste; this becomes important because items that are not recyclable will eventually clog up the environment and create trash from cups to the way a business prints agendas and maps.

Over the next section, this study presents a brief explanation on the theoretical literature regarding organizational strategic capabilities, eco-friendly strategy implementation, business' performance, and present the hypotheses to be tested. In the research methodology section, the study describes the characteristics of the sample firms, defining the variables, and present the methodological explanations. In the last section, the results, discussions, research implications over the industry, governmental policy, and further research avenue presented just before the concluding remarks.

\section{LITERATURE REVIEW}

\subsection{Organizational Strategic Capabilities}

Upon the same industry, close competitors show differences in their competitive behavior. According to the resource-based theory (RBT), the competitive heterogeneity is determined by the differences in each players' resources and capabilities that in turn affects their competitive advantage or disadvantage (Barney, 1991; Helfat \& Peteraf, 2003; Sirmon, Gove, \& Hitt, 2008). These capabilities according to Day (1994) known as organizational or strategic capabilities, spread around different functional areas, actively involve many different personalities whose came from different managerial levels, and serve multiple objectives. It also includes outside-in 
process that involves marketing capabilities and market sensing capabilities; inside-out processes that involves, and spanning processes new product/service development (Amit \& Schoemaker, 1993). It is the capabilities by which organizations' resources are acquired and deployed in ways that match the firm's market environment that explains interorganizational performance variance over time (Teece, Pisano, \& Schuen, 1997; Eisenhardt \& Martin, 2000; Makadok, 2001; Teece, 2007), involve complex coordinated patterns of skills and knowledge that, over time, become embedded as organizational routines (Grant, 1991).

This study follows the five strategic capabilities from Desarbo et al., (2005) can be identified, which are: marketing capabilities, market-linking capabilities, technological capabilities, information technology capabilities, and management capabilities. Marketing capabilities are organizational capacities which are related to market resource deployment (e.g., Danneels, 2007), concerns in individual marketing mix processes (Vorhies \& Morgan, 2005). Marketlinking capabilities concerned with channel and customer linking, help the organization to capture any shifting and changing in customers' needs, wants, and buying behaviors. Technological capabilities allow organization to respond swiftly to changing customer needs and to exploit its technological strengths most effectively to keep costs down and/or differentiate its offerings (Day, 1994). Information technology capability help the organization diffuse market information effectively across all relevant functional areas that it can exploit to direct the new product development process. Finally, management-related capabilities support all the above and include human resource management, financial management, profit, and revenue forecasting, among others (Desarbo et al., 2005).

\subsection{Eco-Friendly Strategy Implementation}

The whole purpose of eco-friendly development planning is efficient use of resources to create more business value while maintaining environmental sustainability. Firm's value can be maximized and the negative effects can be minimized through the implementation of well planned strategies (Azevedo, Carvalho, \& Machado, 2011). Over the last decades, a growing number of companies are integrating sustainability concern into strategic and operational decision-making processes alongside more traditional business rationals (Thomas \& Lamm, 2012). Eco-friendly strategy implementation consists of environmentally responsible operations that cover aspects of consumption of energy, water, and other resources, food waste production, waste management, pollution emitions, and disruption of wildlife habitats, by recreational activities (Shah, 2011).

Further exploration needs to be extended due to the increasing inquires toward environmental sustainability issues in the services sector which has often been described as destroying the environment 'silently' (Leonidou, Leonidou, Fotiadis \& Zeriti, 2013). Gil and Jiminez (2001) also examined several ways to reduce the negative impact on the natural environment, including quantification of environmental costs and savings, environmental training programs, green purchasing policies, energy and water-saving actions, and recycling. Assessment on the causalities among the strategic capabilities and strategic decisions to implement eco-friendly strategy are currently needs some further exploration on the effect of the endowment of these capabilities upon strategic decisions to implement eco-friendly strategy, and furthermore, their impact on business performance. In order to reach the eco-competitiveness (Esty \& Winston, 2009) that reffers to environmental competitiveness as a shared competitiveness of the 
organization, environmental management activities are highy needed (Schaltegger \& Wagner, 2011). Thus, these following hypotheses were developed:

Hypothesis 1a: Marketing capabilities has positive and significant effect on managerial decision in implementing eco-friendly strategy.

Hypothesis 1b: Market-linking capabilities has positive and significant effect on managerial decision in implementing eco-friendly strategy.

Hypothesis 1c: Technological capabilities has positive and significant effect on managerial decision in implementing eco-friendly strategy.

Hypothesis 1d: Information technology capabilities has positive and significant effect on managerial decision in implementing eco-friendly strategy.

Hypothesis 1e: Management capabilities has positive and significant effect on managerial decision in implementing eco-friendly strategy.

\subsection{Eco-Friendly Strategy Implementation and Business Performance}

Over the last two decades, studies have been developed to measure the effect of corporate responsibility and sustainability on organizational performance. However, mixed results were provided, opening the debate on how corporate responsibility and sustainability could have positive contributions to overall business performances. Author such as Golicic and Smith (2013) perform a meta-analytical approach to resolve the issue, resulting from 159 sustainability articles examining performance outcomes, shows strong positive effects of environmental design and production practices on market-based, operational-based, and accounting-based performance. Aligned with the work of Orlitzky, Schmidt \& Rynes (2003) Lothat have also conducted a metaanalytical approach, resulting a positive impact on the firms' performance implications of social and environmental practices from the 52 previous studies.

An eco-friendly strategy implementation practically is a state where organization put into actions all characteristics of the proactive environmental strategy. Proactive environmental strategy itself is defined as a pattern of organizational practices beyond the requirements of environmental regulations and standard actions aiming to reduce the environmental impact of operations (Sharma, 2000; Aragon-Correa \& Sharma, 2003). It also implies strong managerial practices that allows an organization to meet governments' regulations, results in additional cost savings that reflected in less freaquent environmental inspections, fines, and penalties (Bansal, 2005; Lo, Yeung \& Cheng, 2012). Over the resource-based perspective on coroporate environmental strategy (Hart, 1995; Buysse and verbeke, 2003), consistency toward investments in resource domains are manisfested in the organization's environmental proactiveness. Degree of environmental proactiveness thus plays a significant role in determining organizational capability to achive sustained competitive advantage (Moreno \& Reyes Rodriguez, 2013).

Since capabilities are difficult to imitate nor substitute, any firms that most succesfully cultivates these capabilities will outperform its competitors in the long run (Hitt \& Ireland, 1986; Hitt, Ireland, \& Hoskisson, 1997; Hansen, Perry \& Reese, 2004). While the performance effects of 
strategic resources (Barney \& Arikan, 2001; Crook, Ketchen, Combs, \& Todd, 2008), highlight the need to understand how managers effectively utilize these resources (Sirmon, Hitt, \& Ireland, 2007). Following York (2009), the assessment on the business performance uses the logic of Economic Value Added which commonly used to report on value created during a given time period (quarterly, annually, etc) and is typically used as a "top down" measure of the entire organizational performance (Harris, 1997) that is transformed into 2 aspects, which are differentiated cost savings, increased revenue and market share, and financial performance of the strategic business units. As green marketing strategies increasing, it is important to firms incorporate environmentally friendly strategy implementation as a part of triple bottom-line performance evaluation (Cronin, Smith, \& Martinez, 2011). It is also strengthening the findings upon the positive effect of social-environmental responsibility on hotel performance (Rodriguez \& Cruz, 2007). Thus, these following hypotheses were developed:

Hypothesis 2a: Eco-friendly strategy implementation have positive and significant effect on business performance.

Hypothesis 2b: Eco-friendly strategy implementation mediates the relationship between marketing capabilities and business performance.

Hypothesis 2c: Eco-friendly strategy implementation mediates the relationship between marketlinking capabilities and business performance.

Hypothesis 2d: Eco-friendly strategy implementation mediates the relationship between technological capabilities and business performance.

Hypothesis 2e: Eco-friendly strategy implementation mediates the relationship between information technology capabilities and business performance.

Hypothesis 2f: Eco-friendly strategy implementation mediates the relationship between management capabilities and business performance. 
Figure 1. Hypothesized Model

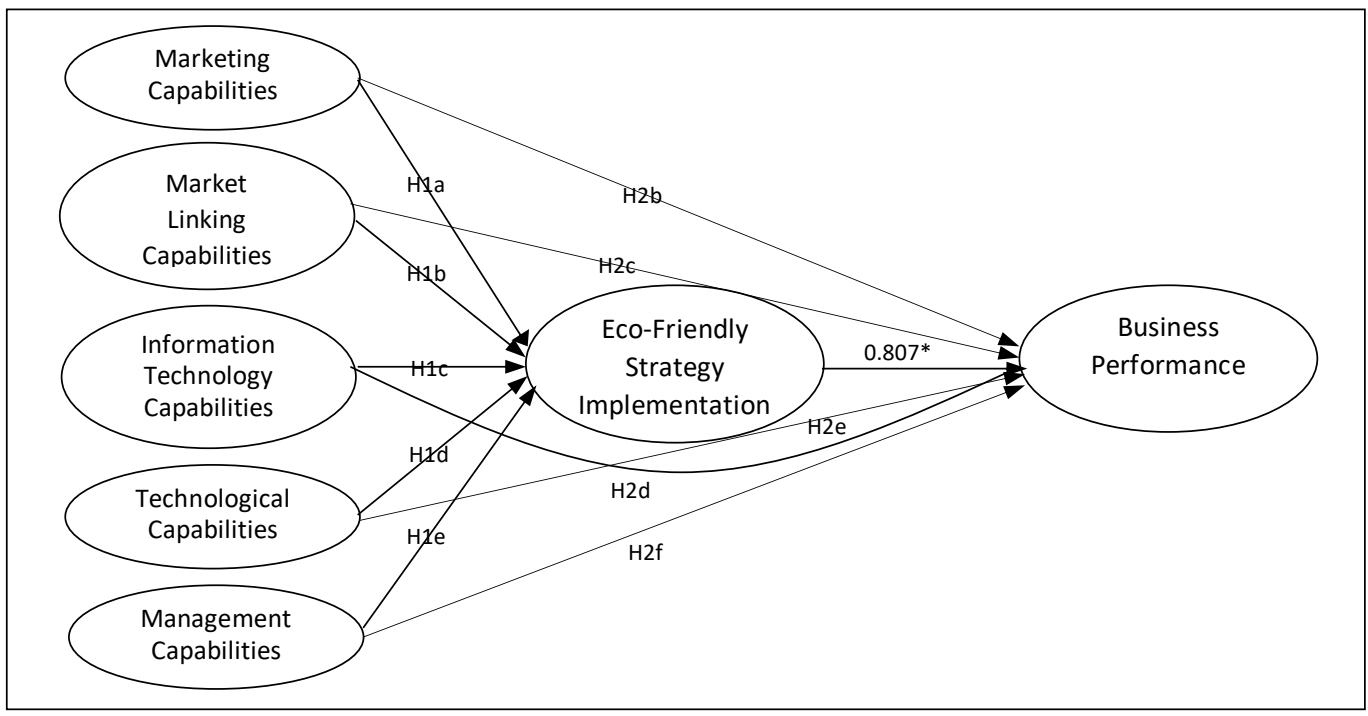

\section{METHODOLOGY}

\subsection{Sampling and Data Collection}

Sample hotels were selected from several major cities in Indonesia, including Jakarta (20 hotels), Bogor (15 hotels), Bandung (15 hotels), Semarang (20 hotels), Yogyakarta (20 hotels), Solo (15 hotels, Surabaya (20 hotels), Bandar Lampung (15 hotels), Pekanbaru (15 hotels), Palembang (15 hotels), Medan (20 hotels), Padang (15 hotels), Samarinda (15 hotels), Balikpapan (15 hotels), Makassar (15 hotels), Manado (15 hotels), Bali (20 hotels) and Lombok islands (15 hotels), with the cities' rapid developments as main consideration. This study focused on tourist and business hotels rated at two-stared and above. According to National Statistics Bureau of Indonesia (2017), there are 2,387 stars hotels across 34 provinces in Indonesia, with at least 233,007 hotel rooms, the average occupancy rate around $65 \%$, and average numbers of guests at least 174,168 per day.

This study aimed to reach $10 \%$ from the total population 2,387 hotels or approximately selected 240 hotel chains formed our sampling frame. This $10 \%$ sample frame is expected to capture the major sales of the industries with some considerations, including their occupancy rate are above industry average and selected hotels are compliment with good review from major on-line major travel agents, and listed at least in the first 3 pages of the on-line travel agents' websites indicating that the selcted hotels are in the top search. To reduce the risks of lower response rate, 300 hotel chains located in selected cities were invited in this research. Senior managers in these hotels were identified as target informants because they have plentiful information and knowledge about key factors relevant to the questions posed in this study. Questionnaires were delivered to all 300 hotels by using the method of conventional mail and one reminder of questionnaire were delivered via electronic mail system. 


\subsection{Measurement Development and Validation}

This study follow Desarbo et al., (2005) in using an eleven (11) point scale to obtain levels of agreement, where 0 represented "Strongly Disagree" and 10 represented "Strongly Agree". In total, we asked 65 different questions as an indicator of measured variables. The 11-point Likerttype scales (from 0 to 10 ) were chosen for the four strategic capability scales. Song and Parry (1997) suggest that this format is better understood across multiple nations than are the 1-7 or 16 scales more commonly seen in North American research, because of their structural similarities to the metric system. The five major capability areas were explicitly measured using all these scales and have been appropriately validated in previous research studies (Desarbo et al., 2005, Desarbo, Benedetto, Jedidi, \& Song, 2006; Song, Benedetto, \& Nason, 2007). Marketing capabilities (6 items); market linking capabilities (6 items); technological capabilities (6 items); information Technology capabilities (6 items) and management capabilities (6 items). Measurement of eco-friendly strategy implementation taken from 14 items as indications of proactive environmental strategy that also been measured by Murillo-Luna, Garces-Ayerbe, and Rivera-Torres (2008), also in an 11-point scale was used to obtain levels of agreement, where 0 represented "Strongly Disagree" and 10 represented "Strongly Agree".

Finally, performance data were collected. We use assessment tools taken from Desarbo et al., (2005) (9 items). The measures collected were: PROFIT, ROIPEC, ROI (return on investment), ROA (return on assets), RMS (relative market shares), CUSRET (overall customer retention), sales growth rate, overall profit margin relative to the objective for this business unit, overall sales relative to the objective for this business unit, and overall return on investment relative to the objective for this business unit. As representatives of the measurement of EVA, we use 2 dimensions: differentiated cost savings and increased revenue and market share (12 items). Differentiated cost savings (Willard, 2002) reflected toward 3 sub-dimensions: reduced operating and service producing expenses; risk reduction; and decreased employee expense. Second dimension is increased revenue and market share, obtained through access to markets; preferential purchasing; and increased innovation (York, 2009). To measure performance, this study also used an 11-point scale to elicit levels of agreement, with values ranging from 0 (much worse than our competitors) to 10 (much better than our competition.

\subsection{Data Analysis}

Causal tests were done using Statistical Package for the Social Sciences (SPSS) 22 to evaluate the relationships between study variables as stated in the hypotheses as the model in Figure 1, and the results of descriptive statistics are presented in the Table 1 below. Mean score of Marketing, Market Linking, Information Technology, Technological, and Management Capabilities indicates that each capabilities of the participating hotels are high. Similar indication also shown upon Eco-Friendly Strategy Implementation and Business Performance that each of them shows high value in the mean score. 
Table 1. Descriptive Statistics

\begin{tabular}{|c|c|c|c|c|c|c|c|c|c|c|}
\hline & \multirow{2}{*}{ Variables } & \multirow[b]{2}{*}{ Mean } & \multirow{2}{*}{$\begin{array}{l}\text { Std. } \\
\text { Dev. }\end{array}$} & \multicolumn{7}{|c|}{ Correlations } \\
\hline & & & & 1 & 2 & 3 & 4 & 5 & 6 & 7 \\
\hline 1 & $\begin{array}{l}\text { Marketing } \\
\text { Capabilities }\end{array}$ & 8.064 & 1.446 & 1.000 & & & & & & \\
\hline 2 & $\begin{array}{l}\text { Market-Linking } \\
\text { Capabilities }\end{array}$ & 8.313 & 1.369 & 0.906 & 1.000 & & & & & \\
\hline 3 & $\begin{array}{l}\text { Information } \\
\text { Technology } \\
\text { Capabilities }\end{array}$ & 7.845 & 1.657 & 0.695 & 0.664 & 1.000 & & & & \\
\hline 4 & $\begin{array}{l}\text { Technological } \\
\text { Capabilities }\end{array}$ & 7.908 & 1.645 & 0.695 & 0.681 & 0.880 & 1.000 & & & \\
\hline 5 & $\begin{array}{l}\text { Management } \\
\text { Capabilities }\end{array}$ & 8.051 & 1.542 & 0.754 & 0.776 & 0.750 & 0.785 & 1.000 & & \\
\hline 6 & $\begin{array}{l}\text { Eco-Friendly } \\
\text { Strategy } \\
\text { Implementation }\end{array}$ & 7.707 & 1.733 & 0.637 & 0.578 & 0.769 & 0.785 & 0.718 & 1.000 & \\
\hline 7 & $\begin{array}{l}\text { Business } \\
\text { Performance }\end{array}$ & 7.792 & 1.685 & 0.693 & 0.649 & 0.711 & 0.756 & 0.709 & 0.807 & 1.000 \\
\hline & 109 & & & & & & & & & \\
\hline
\end{tabular}

\section{RESULTS AND DISCUSSION}

\subsection{Demographic Characteristics}

The data collection period lasted from March until July 2017, as many as 127 responses were received, resulting in 109 valid responses, yielding 6 responses from two-star hotel, 44 from three-star hotels, 47 from four-star hotels, and 12 from five-star hotels. About $71 \%$ of participating hotels are part of an international network hotel association, and $29 \%$ hotels are part of a local or domestic network hotel association. From the business scale category, about $22 \%$ of the response was received from hotels which accommodate $25-99$ guest rooms, $47 \%$ from hotels with 100-200 guest rooms, $19 \%$ from hotels with 201-300 guest rooms, and $12 \%$ from hotels with more than 300 guest rooms. As many as 109 middle-to top-level management employees were involved, with the total of $75 \%$ were occupied as senior-level and top-level management, about $13 \%$ at middle-management roles, and the remaining $12 \%$ are in the lower-level management. Respondents in top-level management have their tenure with approximately 25-30 years of services, senior-middle management about 10-24.5 years of services, and lower-level management. Responses from lower-level management are excluded from the study for the fitness reasons regarding business performance indicators that can only be answered by mid-level or senior level managers. 
Table 2: Validity Test Results

\begin{tabular}{|c|c|c|c|c|c|}
\hline "Variable & Indicator & Loading Factor & Variable & Indicator & "Loading Factor \\
\hline & $\mathrm{MC1}$ & 0.872 & & MLC1 & 0.861 \\
\hline & $\mathrm{MC} 2$ & 0.839 & & MLC2 & 0.923 \\
\hline Marketing & $\mathrm{MC} 3$ & 0.857 & Market-linking & MLC3 & 0.794 \\
\hline \multirow{4}{*}{ Capabilities } & MC4 & 0.885 & Capabilities & MLC4 & 0.874 \\
\hline & MC5 & 0.879 & & MLC5 & 0.826 \\
\hline & MC6 & 0.698 & & MLC6 & 0.876 \\
\hline & ITC1 & 0.823 & \multirow{6}{*}{$\begin{array}{l}\text { Technological } \\
\text { Capabilitie }\end{array}$} & TC1 & 0.922 \\
\hline \multirow{5}{*}{$\begin{array}{l}\text { Information } \\
\text { Technology } \\
\text { Capabilities }\end{array}$} & ITC2 & 0.873 & & TC2 & 0.921 \\
\hline & ITC3 & 0.945 & & TC3 & 0.954 \\
\hline & ITC4 & 0.876 & & TC4 & 0.886 \\
\hline & ITC5 & 0.894 & & TC5 & 0.918 \\
\hline & ITC6 & 0.870 & & TC6 & 0.885 \\
\hline \multirow{6}{*}{$\begin{array}{l}\text { Management } \\
\text { Capabilities }\end{array}$} & MAN1 & 0.889 & \multirow{14}{*}{$\begin{array}{l}\text { Eco-friendly } \\
\text { Strategy } \\
\text { Implementation }\end{array}$} & ESI1 & 0.763 \\
\hline & MAN2 & 0.926 & & ESI 2 & 0.815 \\
\hline & MAN3 & 0.916 & & ESI 3 & 0.789 \\
\hline & MAN4 & 0.841 & & ESI 4 & 0.861 \\
\hline & MAN5 & 0.907 & & ESI 5 & 0.808 \\
\hline & MAN6 & 0.871 & & ESI 6 & 0.755 \\
\hline \multirow{6}{*}{$\begin{array}{l}\text { Differentiated } \\
\text { Cost Savings }\end{array}$} & DCS1 & 0.679 & & ESI 7 & 0.867 \\
\hline & DCS2 & 0.779 & & ESI 8 & 0.815 \\
\hline & DCS3 & 0.861 & & ESI 9 & 0.861 \\
\hline & DCS4 & 0.829 & & ESI 10 & 0.852 \\
\hline & DCS5 & 0.704 & & ESI 11 & 0.672 \\
\hline & DCS6 & 0.673 & & ESI 12 & 0.781 \\
\hline \multirow{9}{*}{$\begin{array}{l}\text { Financial } \\
\text { Performance }\end{array}$} & FP1 & 0.815 & & ESI 13 & 0.798 \\
\hline & FP2 & 0.826 & & ESI 14 & 0.752 \\
\hline & FP3 & 0.736 & \multirow{7}{*}{$\begin{array}{l}\text { Increased } \\
\text { Revenue } \\
\text { Market Share }\end{array}$} & IRM1 & 0.862 \\
\hline & FP4 & 0.845 & & IRM2 & 0.865 \\
\hline & FP5 & 0.835 & & IRM3 & 0.843 \\
\hline & FP6 & 0.794 & & IRM4 & 0.827 \\
\hline & FP7 & 0.810 & & IRM5 & 0.808 \\
\hline & FP8 & 0.832 & & IRM6 & 0.608 \\
\hline & FP9 & 0.890 & & & \\
\hline
\end{tabular}

Table 3: Reliability Test Results

\begin{tabular}{cc}
\hline \hline Reliability & Cronbach-Alpha \\
\hline Marketing Capabilities & 0.912 \\
Market-linking Capabilities & 0.926 \\
Information Technology Capabilities & 0.941 \\
Technological Capabilities & 0.960 \\
Management Capabilities & 0.946 \\
Eco-friendly Strategy Implementation & 0.953 \\
Differentates Cost Savings & 0.842 \\
Increased Revenue Market Share & 0.852 \\
Financial Performance & 0.937 \\
\hline \hline
\end{tabular}




\subsection{Result of the Hypothesized Mode}

Data from Table 2 depicts that all the loading factors from the indicators are higher than 0.55 . According to Hair, Black, Babin, \& Tatham (2010:117), sample size will determine the required value of loading factors. This study use 109 data resulted from the primary data collection, thus, the required value of loading factors is 0.55 , resulting a total 65 valid items. As for the reliability test, Cronbach Alpha were used to determine the consistency of the measures variables if tested in different time. Table 3 depicts the results from reliabilty tests of this study. According to Hair et al., (2010:125), in order to reach the reliablity requirement, the Cronbach Alpha should at least reach 0.70. Table 3 shows that all the Cronbach Alpha are higher than 0.70 which indicate all measures variables are reliable. $(\alpha$ of SBU Strategic Capabilities $=0.938$, Eco-Friendly Strategy Implementation $=0.951$, and Business Performance $=0.787$ ). Evidently the study hypotheses were corroborated. The result indicated that Strategic Capabilities has positive and significant effects on Eco-Friendly Strategy Implementation as hypothesized in H1; and Eco-Friendly Strategy Implementation has positive and significant effects on Business Performance as hypothesized in $\mathrm{H} 2$.

Figure 2: The Result Model

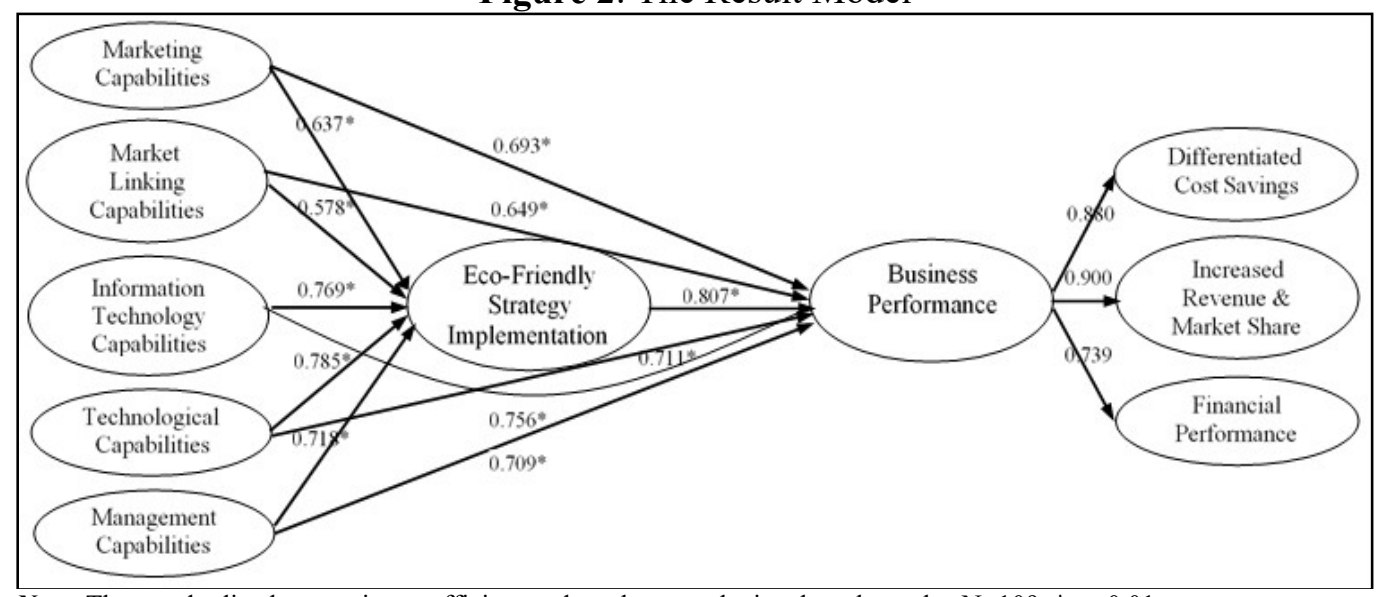

Note: The standardized regression coefficient and t-values are depicted on the paths, $\mathrm{N}=109,{ }^{*} p<0.01$

Furthermore, in order to measure the mediating effect, Baron and Kenny's four steps test of mediation can be evaluated to understand the mechanism through which each Capabilities affects Business Performance though Eco-Friendly Strategy Implementation as the intervening variable as hypothesized in $\mathrm{H} 2 \mathrm{a}$ until $\mathrm{H} 2 \mathrm{f}$. The four steps consist of testing the causal relationship in unmediated form of Capabilities to Business Performance, followed by carrying out causal test from Capabilities towards Eco-Friendly Strategy Implementation. Afterward, the effect of Capabilities towards Business Performance by controlling for Eco-Friendly Strategy Implementation was tested, and finally mediation is established by looking at the effect significance from the previous step with the outcome of complete or partial mediation result. The mediation test showed that Marketing, Market Linking, Information Technology, Technological, and Management Capabilities affects Business Performance significantly as shown in Figure 1. It 
is established that there is a partial mediation relationship between Marketing, Market Linking, Information Technology, Technological, and Management Capabilities and Business Performance through the process of Eco-Friendly Strategy Implementation, as it was found that there is a reduction of direct effect between each Capabilities and Business Performance where it is still statistically significant after Eco-Friendly Strategy Implementation was included $(\beta>0.0)$ (Baron and Kenny, 1986).

\subsection{Discussion}

Elaboration of eco-friendly strategy implementation on the relationship between organizational strategic capabilities and business performance indicates some important findings, including the effectiveness of the strategy empirically will affect the business performance significantly. From the study, we found that organizational strategic capabilities can also directly affect the business performance, without the mediating role of eco-friendly strategy implementation. These findings also show some indications that the theory explaining the causal effects of organizational capabilities upon business performance are reliable even in the context of emerging countries. An eco-friendly strategy stimulates hotels to generate high margin products by implementing cutting-edge technologies which can enchance profit growth (Menguc \& Auh, 2010). This study enrich previous study which also found that the hotel industry hold 3 main characteristics with regards the natural environment sustainability: (1) they are usually heavy users of resources such as energy with its potential negative effects on the environment; (2) the industry relies on ecological aspects in order to fulfil customer's expectations and experiences; (3) the industry always in the situation to deal with strict environmental regulations from government, and other environmental pressure from their stakeholders (Fineman \& Clarke, 1996; Alvarez-Gil, BurgosJiminez, \& Cespedes-Lorente, 2001).

Among the five organizational strategic capabilities, technological capabilities has the highest score in reflecting the construct. Technological capabilities allows participating hotels to develop new services, improve business process, understand and predicting all possible technological changes in the industry; at the same time improving the hotels' facilities through the implementation of new and advance technology, complemented by improvement in quality control skills. Our findings indicates that the the higher effect of Information technology capabilities derived from the sufficient capacity and ability of the hotel in developing and maintaining IT systems to support new project development projects, facilitating cross-functional integration, facilitating internal knowledge creation as Powell and Dent-Micallef (1997) suggested. Contributing hotel managers view those capabilities as slightly more important in defining strategic decisions to implement a more proactive ways toward environmental strategy.

From the sample of 109 hotel chains in Indonesia, we also found that marketing capabilities of the strategic business units play significant roles in understanding more about their customers, competitors, improving the ability to integrate different marketing activities to deeply understand the characteristics of each market segment and to decide the target markets, toward the capability to improve the effectiveness of pricing and advertising program. At the same time, market linking capabilities that consist of the capabilities to sense any changes in market needs, wants, or other characteristics; creating and managing durable and valuable customer, suppliers, and all channel member (i.e. conventional and online travel agents) relationships and thus boundings; the ability to retain customers through excellent service providing. Those are the capabilities that 
could create differentiation that could benefits and allow the hotel to experience preferential treatment from customers and other stakeholders (Sharma \& Vredenburg, 1998) among their close competitors and through that allows competing hotel to create more opportunities for business growth, increasing sales and by then business profits through the exploration of new markets that has not been served before where the competition is scarce (Menguc \& Auh, 2010).

Hotels as a dominant player in tourism industry play significant role in competitive scenario where businesses in the industry are required to reconsider thier roles and positions in the preservation of natural resources initiatives. However, differences in managerial approaches and decisions toward environmental problems are remain heterogeneous, depending on some determinants, such as managerial values, organizational resources, market industry conditions (Aragon-Correa \& Sharma, 2003; Delmas \& Cuerel-Burbano, 2011), or managerial discretion (Hambrick \& Finkelstein, 1987; Peteraf \& Reed, 2007). All the participating hotel managers were asked to rank the implementation of eco-friendly strategy, and the results show that all the participating hotels have already implemented the 14 initiatives with different level of involvement. The implementation of eco-friendly strategy have significantly positive impact on business performance, where every improvement on the implementation of the initiatives will caused an improvement both in cost saving activities, increased revenue and market share, and finally incrases in financial performance. It makes the findings of this current study are consistent with the findings of Aragon-Correa and Sharma (2003) which was an expanded research of Hart (1995) who has affirmed that a proactive environmental strategy offers organizations competitive advantages because it allows businesses to deploy rare, uniques, and complex capabilities that are hard to imitate; allows organizations to evolve and align their strategy with the changing and uncertain environment (Peteraf \& Bergen, 2003).

This study also found that the eco-friendly strategy involves the implementation of innovative environmental modification, indicated with high degree of standrdized loading factor in technological and information technology capabilities that are dependent on identifiable processes. These capabilities are tacit, firm-specific, socially complex, and linked to differentiation and cost advantages as Aragon-Correa and Sharma (2003) suggested, that is also idiosyncratic and can be identified as the source of organization's competitive advantages. Specifically, current study support what has already found by Sharma, Aragon-Correa, \& Rueda (2007) in their study toward contingent influence of organizational capabilities on proactive environmental strategy in the service sector. Both studies resulted a positive relations between the organizational capabilities and proactive environmental or eco-friendly strategy. The ecofriendly strategy implementation is also non-replicable and non-imitable since it requires not only a logical sequential process in reconfiguring organizational resources, but also shows the commitment, organizational involvement, and coordination among all members in each organization as Sharma and Vredenburg (1998) and Barney \& Arikan (2001) suggested.

\subsection{Practical Implications}

Hotel industry as one of the most important parts of the tourism sector in Indonesia has a very important role in participating in the campaign of eco-friendly business implementation. We suggest the operating hotels to to develop new line of services in order to improve business process. Advance technological capabilities may help the hotels to understand and predict market and other changes in the industry. Operating hotels are also suggest to enhance greener products 
resulting from new and advance technology, complemented by improvement in quality control skills. From our findings we also suggest operating hotels to improve their capacities in developing and maintaining IT systems to support new project development projects, facilitating cross-functional integration, facilitating internal knowledge creation. It is also important to operating hotels to collaborate with the internal and external networks in order to facilitate market knowledge creation, bridging internal communication across different functions, departments, or levels of the organization, and at the same time build a reliable platform to facilitate external communication toward hotels' suppliers, customers, and other channel members.

Finally, from the findings of the study, implications regarding policy implementation can be drawn. First, there should be a consistency in law and regulations to protect the natural resources between the local government and central government of Indonesia. The local and central government are suggested to develop environmental sustainability-based policies as a guidance in the implementations of sustainable development, and most important, manage to evaluate, watch over and take any necessary penalties as consequences of violations to the environmental regulations. The law and regulations should at least consist of control management systems to contain negative impact of business operations in the hotel industry upon natural resources, such as policies regarding water and sanitation management, waste management systems including electrical equipment wastes that might harm the environment. Third and most of all, local and central government are suggested to control the license upon the numbers of operating hotels in one area, including the requirement that regulates the minimum distance between one hotel to another, especially in major cities where the supply of newly opened hotels increase in significant level in these current years. Consider that the higher the number of the operating hotels, the higher the potential risk of environmental and natural resource damages shall arise.

\section{CONCLUSION}

This study succeeded in verifying the three hypotheses tested, that the organizational strategic capabilities has a significant positive effect on eco-friendly strategy implementation, which means that the higher the organizational capabilities, will be the higher the possibility to implement eco-friendy strategy. A result that can be categorized as a new finding is that the organizational strategic capabilities shows a positive direct effect on business performance, leaving the mediating effect of strategy implementation as partially mediated. This finding should be tested toward further research, in the different contexts of businesses or tested over different industries. Finally, tests on the effect of eco-friendy strategy implementation on firm performance have positive relationship influence pattern, it means that decision to respond to the pressure to be more environmentaly friendly in doing business can increase or decrease the company performance. When the company gives a positive response, it will influence the financial performance and vice versa, if the company responds that is considered negative then th effect on the company's financial performance will also be negative or decrease the company's performance.

This study has limitations in terms of the limited response rate. Only 127 responses from 300 bundles of questionnaires were sent to the sample group, and only 102 that could be included in the testing stage for various reasons, such as incomplete filling, especially on the part of the 
firm's performance, which indicated doubts and concerns that confidential information would be exposed publicly, there is a response with patterned answers so that the research team decides not to include it for the further test, incomplete demographic data is another reason. With these limitations, researchers recommend the further research to apply better methods of data collections and monitoring procedures. The addition of measurement variables which are possible to be antecedent factors affecting managerial decisions to implement eco-friendly strategy should be considered, especially in relation to managing pressure from different social groups, managers' perception on environmental uncertainty or environmental dynamism. Other antecedent factors that have not been included yet in this research model are aspects of the ownership status where family-owned businesses most likely have different characteristics with public-owned companies, which theoretically influences the management's view over the decision-making stages.

\section{ACKNOWLEDGEMENT}

This research was supported by Indonesia Ministry of Finance through Lembaga Pengelolaan Dana Pendidikan (LPDP) for Indonesia Educational Scholarship.

\section{REFERENCES}

Alvarez-Gil, M. J., Burgos-Jiminez, J., \& Cespedes-Lorente, J. J. (2001). An analysis of environmental management, organizational context, and performance of Spanish hotels. Omega, 29(6), 457-471.

Amit, R., \& Schoemaker, P. (1993). Strategic assets and organizational rent. Strategic Management Journal, 14(1), 33-46.

Aragon-Correa, J. A., Hurtado-Torres, N., Sharma, S., \& García-Morales, V. (2008). Environmental strategy and performance in small firms: a resource-based perspective. Journal of Environmental Management, 86(1), 88-103.

Aragon-Correa, J. A., \& Rubio-Lopez, E. A. (2007). Proactive corporate environmental strategies: myths and misunderstandings. Long Range Planning, 40(3), 357-381.

Aragon-Correa, J. A., \& Sharma, S. (2003). A contingent resource-based view of proactive corporate environmental strategy. Academy of Management Review, 28(1), 71-88.

Aragon-Correa, J. A. (1998). Strategic proactivity and firm approach to the natural environment. Academy of Management Journal, 41(5), 556-567.

Azevedo, S. G., Carvalho, H., Machado, V. C. (2011). The influence of green practices on supply chain performance: A case study approach. Transportation Research Part E Logistics and Transportation Review, 47(6), 850-871.

Bansal, P. (2005). Evolving sustainability: A longitudinal study of corporate sustainable development. Strategic Management Journal, 26(3), 197-218.

Barney, J. B., \& Arikan, A. M. (2001). The resource-based view: Origins and implications. In M. A. Hitt, R. E. Freeman, \& J. S. Harrison (Eds). Handbook of Strategic Management, 124-188, Oxford, UK, Blackwell.

Barney, J. (1991). Firm resources and sustained competitive advantage. Journal of Management, 17(1), 99-120. 
Baron, R. M., \& Kenny, D. A. (1986). The moderator-mediator variable distinction in social psychological research: Conceptual, strategic, and statistical considerations. Journal of Personality and Social Psychology, 51(6), 1173-1182.

Buysse, K. \& Verbeke, A. (2003). Proactive Environmental Strategies: A Stakeholder Management Perspective. Strategic Management Journal, 24(5), 453- 470.

Chabowski, B., Mena, J. A., Gonzales-Padron, T. (2011). The structure of sustainability research in marketing, 1958-2008: A basis for future research opportunities. Journal of Academy of Marketing Science, 39(1), 55-70.

Christmann, P. (2000). Effects of "The best practices" of environmental management on cost advantage: The role of compementary assets. The Academy of Management Journal, 43(4), 663-680.

Clarkson, M. E. (1995). A Stakeholder Framework for Analyzing and Evaluating Corporate Social Performance. Academy of Management Review, 20(1), 92-117.

Cronin, J. J., Smith, J., Gleim, M. R., Ramirez, E., \& Martinez, J. D. (2011). Green marketing strategies: an examination of stakeholders and the opportunities they present. Journal of the Academy of Marketing Science, 39(1), 158-174.

Crook, T. R., Ketchen, D. J., Combs, J. G., \& Todd, S. Y. (2008). Strategic resources and performance: A meta-analysis. Strategic Management Journal, 29(11), 1141-1154.

Day, G. S. (1984). The capabilities of market-driven organizations. Journal of Marketing, 58(4), $37-52$.

Danneels, E. (2007). The process of technological competence leveraging. Strategic Management Journal, 28(5), 511-533.

Delmas, M. A., \& Cuerel-Burbano, V. (2011). The drivers of greenwashing. California Management Review, 54(1), 64-87.

Desarbo, W. S., Benedetto, A. D., Song, M., \& Sinha, I. (2005). Revisiting the Miles and Snow strategic framewoek: Uncovering interrelationships between strategic types, capabilities, environmental uncertainty, and firm performance. Strategic Management Journal, 26(1), 47-74.

Desarbo, W. S., Benedetto, A. D., Jedidi, K., \& Song, M. (2006). Identifying sources of heterogeneity for empirically deriving strategic types: A constrained finite-mixture structural-Equation Methodology. Management Science, 52(6), 909-924. doi: $10.1287 /$ mnsc. 1060.0529 .

Eisenhardt, K. M., \& Martin, J. A. (2000). Dynamic capabilities: What are they? Strategic Management Journal, 21(10-11), 1105-1121.

Esty, D. C., \& Winston, A. S. (2009). Green to Gold. Hoboken, New Jersey: John Wiley \& Sons. Inc.

Fineman, S., \& Clarke, K. (1996). Green stakeholders: industry interpretations and response. Journal of Management Studies, 33(6), 715-730.

Gil, M., \& Jimenez, J. (2001). An analysis of environmental management, organizational context, and performance of Spanish hotels. Omega, 29(6), 457-471.

Golicic, S., \& Smith, C. D. (2013). A meta-analysis of environmentally sustainable supply chain management practices and firm performance. Journal of Supply Chain Management, 49(2), 78-95.

Grant, R. M. (1991). The resource-based theory of competitive advantage: implications for strategy formulation. California Management Review, 33(3), 114-135.

Hair, J. F., Black, W. C., Babin, B. J., \& Tatham, R. L. (2010). Multivariate Data Analysis: A Global Perspective. Upper Saddle River, NJ: Pearson Education. 
Hambrick, D. C., \& Finkelstein, S. (1987). Managerial discretion: a bridge between polar views of organizational outcomes. Research in Organizational Behavior, 9, 369-406.

Hansen, M. H., Perry, L. T., \& Reese, C. S. (2004). A Bayesian operationalization of the resource-based view. Strategic Management Journal, 25, 1279-1295.

Harris, R. D. (1997). Stock markets and development: A re-assessment. European Economic Review, 41(1), 139-146.

Hart, S. L. (1995). A natural-resource-based view of the firm. The Academy of Management Review, 20(4), 986-1014.

Helfat, C. E., \& Peteraf, M. A. (2003). The dynamic resource-based view: Capability Lifecycles. Strategic Management Journal, 24(10), 997-1010.

Hitt, M. A., Bierman, L., Shimizu, K., \& Kochhar, R. (2001). Direct and moderating effects of human capital on strategy and performance in professional service firms: A resourcebased perspective. Academy of Management Journal, 44(1), 13-28.

Hitt, M. A., Ireland, R. D., \& Hoskisson, R. E. (1997). Strategic management: Competitiveness and globalization. St. Paul: West Educational Publishing.

Hitt, M. A., \& Ireland, R. D. (1986). Relationships among corporate level distinctive competencies, diversification strategy, corporate structure, and performance. Journal of Management Studies, 23(4), 401-16.

Leonidou, L. C., Leonidou, C. N., Fotiadis, T. A., \& Aykol, B. (2015). Dynamic capabilities driving an eco-based advantage and performance in global hotel chains: The moderating effect of international strategy. Tourism Management, 50(C), 268-280. doi: 10.1016/j.tourman.2015.03.005.

Leonidou, L. C., Leonidou, C. N., Fotiadis, T. A., \& Zeriti, A. (2013). Resources and capabilities as drivers of hotel environmental marketing strategy: Implication for competitive advantage and performance. Tourism Management, 35(C), 94-110. doi: 10.1016/j.tourman.2012.06.003.

Lo, C. K. Y., Yeung, A. C. L., \& Cheng, T. C. E. (2012). The impact of environmental management systems on financial performance in fashion and textiles industries. International Journal of Production Economics, 135(2), 561-567.

Makadok, R. (2001). Toward a synthesis of the resource-based and dynamic capability views of rent creation. Strategic Management Journal, 22(5), 387-401.

Menguc, B., \& Auh, S. (2010). Development and return on execution of product innovation capabilities: The role of organizational structure. Industrial Marketing Management, 39(5), 820-831.

Moreno, M., \& Reyes Rodriguez, J. F. (2013). The value of a proactive environmental strategy: An empirical evaluation of the contingent approach to dynamic capabilities. Cuadernos de Administracion, Serie Organizaciones, 26(47), 87-118.

Murillo-Luna, J. L., Garces-Ayerbe, C., \& Rivera-Torres, P. (2008). Why do patterns of environmental response differ? A Stakeholders' pressure approach. Strategic Management Journal, 29(11), 1225-1240.

National Statistics Bureau of Indonesia. (2017). Tingkat Hunian Kamar Hotel 2016. Jakarta: National Statistics Bureau of Indonesia. Retrieved from https:/www.bps.go.id/publications/2017/09/12/5a853ecb441c55920761 f071/tingkathunian-kamar-hotel-2016.httml

Orlitzky, M., Schmidt, F. L., \& Rynes, S. L. (2003). Corporate social and financial performance: a meta-analysis. Organization Studies, 24(3), 403-441. 
Parnell, J. A. (2018). Nonmarket and market strategies, strategic uncertainty, and strategic capabilities: Evidence from the USA. Management Research Review, 42(2), 252-274.

Peteraf, M., Steafano, D. G., \& Verona, G. (2013). The elephant in the room of dynamic capabilities: bringing two diverging conversations together. Strategic Management Journal, 34(12), 1389-1410. doi: 10.1002/smj.2078.

Peteraf, M., \& Reed R. (2007). Managerial discretion and internal alignment under regulatory constraints and change. Strategic Management Journal, 28(11), 1089-1112.

Peteraf, M., \& Bergen, M. E. (2003). Scanning dynamic competitive landscapes: a market-based and resource-based framework. Strategic Management Journal, 24(10), 1027-1041.

Powell, T. C., \& Dent-Micallef, A. (1997). Information technology as competitive advantage: The role of human, business, and technology resources. Strategic Management Journal, 18(5), 375-405.

Rodriguez, F. J. G., \& Cruz, Y. M. A. (2007). Relation between social-environmental responsibility and performance in hotel firms. International Journal of Hospitality Management, 26(4), 824-839.

Rugman, A. M., \& Verbeke, A. (2003). Multinational enterprises and clusters: an organizing framework. Management International Review, 43(3), 151-169.

Schaltegger, S., \& Wagner, M. (2011). Sustainable entrepreneurship and sustainability innovation: categories and interactions. Business Strategy and the Environment, 20(4), 222-237.

Shah, K. U. (2011). Strategic organizational drives of corporate environmental responsibility in the Caribbean hotel industry. Policy Science, 44(4), 321-344.

Sharma, S., Aragon-Correa, J. A., \& Rueda, A. (2007). The contingent influence of organizational capabilities on proactive environmental strategy in the service sector: An analysis of North American and European ski resorts. Canadian Journal of Administrative Sciences, 24(4), 268-283.

Sharma, S. (2000). Managerial interpretations and organizational context as predictors of corporate choice of environmental strategy. The Academy of Management Journal, 43(4), 681-697. DOI: 10.207/1556361.

Sharma, S., \& Vredenburg, H. (1998). Proactive corporate environmental strategy and the development of competitively valuable organizational capabilities. Strategic Management Journal, 19(8), 729-753.

Sirmon, D. G., Gove, S., \& Hitt, M. A. (2008). Resource management in dyadic competitive rivalry: the effects of resource bundling and deployment. Academy of Management Journal, 51(5), 919-935.

Sirmon D. G., Hitt M. A., \& Ireland R. D. (2007). Managing firm resources in dynamic environments to create value: looking inside the black box. Academy of Management Review, 32(1), 273-292.

Song, M., Beneditto, A. D., \& Nason, R. W. (2007). Capabilities and financial performance: The moderating effect of strategic type. Journal of The Academy of Marketing Science, 35(1), 18-34.

Song, M., \& Parry, M. E. (1997). A cross-national comparative study of new product development process: Japan and the United States. Journal of Marketing, 61(2), 1-18.

Teece, D. J. (2007). Explicating dynamic capabilities: the nature and micro foundations of (sustainable) enterprise performance. Strategic Management Journal, 28(13), 13191350. 
Teece, D. J., Pisano, G., \& Schuen, A. (1997). Dynamic capabilities and strategic management. Strategic Management Journal, 18(7), 509-534.

The World Commission on Environment and Development (WCED) (1987). Our Common Future. Oxford: Oxford University Press

Thomas, T. E., \& Lamm, E. (2012). Legitimacy and organizational sustainability. Journal of Business Ethics, 110(2), 191-203. doi: 10.1007/s10551-012-1421-4.

Tsinopoulos, C., S., Sousa, M. P., \& Yan, Ji. (2018). Process Innovation: Open innovation and moderating role of the motivation to achieve legitimacy. Journal of Product Innovation Management, 35(1), 27-48.

Vorhies, D. W., \& Morgan, N. A. (2005). Benchmarking marketing capabilities for sustainable competitive advantage. Journal of Marketing, 69(1), 80-94.

Willard, B. (2002). The sustainability Advantage: Seven Business Case Benefits of a Triple Bottom Line. New Society Publishers: Gabriola Island.

York, J. G. (2009). Pragmatic sustainability: translating environmental ethics into competitive advantage. Journal of Business Ethics, 85(1), 97-109. 